\title{
Tantangan Orang Tua Mendampingi Anak Usia 6-7 tahun Belajar di Rumah selama Pandemi Covid-19
}

\author{
Erika $^{1}$, Agrina ${ }^{2}$, Shally Novita ${ }^{3}$, Maria Komariah ${ }^{4}$ \\ Maternitas Anak, Universitas Riau Pekanbaru, Indonesia(1) \\ Jiwa Komunitas, Universitas Riau Pekanbaru, Indonesia(2) \\ Psikologi Perkembangan, Universitas Padjadjaran, Bandung, Indonesia(3) \\ Keperawatan Dasar, Universitas Padjadjaran, Bandung, Indonesia ${ }^{(4)}$ \\ DOI: $10.31004 /$ obsesi.v6i1.1225
}

\begin{abstract}
Abstrak
Penelitian ini bertujuan untuk mengetahui tantangan orang tua saat mendampingi anak usia 6-7 tahun belajar di rumah selama pandemi COVID-19. Subjek penelitian ini adalah 526 orang tua (ibu) dari anak yang berusia 6-7 tahun (usia rata-rata $=33$ tahun, $S D=4.71$ ) dari $51.60 \%$ laki-laki dan $41.3 \%$ perempuan yang baru mulai bersekolah dimasa pandemi COVID-19. Penelitian ini merupakan penelitian kuantitatif dengan rancangan penelitian cross sectional. Teknik pengambilan data menggunakan google form yang disebarkan melalui grup-grup Whatsapp ibu-ibu yang memiliki anak usia 6-7 tahun dan sudah mulai bersekolah selama satu bulan. Data dianalisis menggunakan komputerisasi. Hasil survey menunjukkan bahwa ibuibu harus menjadi guru pengganti dengan mengajarkan serta menjelaskan tugas-tugas yang diberikan gurunya kepada anak usia 6-7 tahun (66.20\%). Ibu merasa kesulitan mengajarkan dan mendampingi anak usia 6-7 tahun belajar di rumah di masa pandemi COVID-19 (71.10\%). Sebanyak 78.20\% ibu-ibu menginginkan anak-anak kembali belajar di sekolah bersama guru.
\end{abstract}

Kata Kunci: Tantangan orangtua; anak usia 6-7 tahun; belajar selama COVID-19

\begin{abstract}
The objective of this study is to seek out the challenges faced by parents when assisting their 6 to 7 years old children to learn at home during the COVID-19 pandemic. The subjects of this study were 526 parents (mothers) (mean age $=33, S D=4.71$ ) of children aged 6-7 years old (mean age $=6.42, S D=0.81 ; 51.60 \%$ of them were boys and 41.3 - were girls) who had just started school during the COVID-19 pandemic. This research is a quantitative study with a cross-sectional research design. The data collection technique uses google form which is distributed through Whatsapp groups of mothers who have children aged 6 to 7 years old and have started schooling. Data were analyzed using computerization. The survey results show that mothers must become substitute teachers by teaching and explaining the tasks that assigned by the teachers $(66.20 \%)$. Most of the mothers felt difficult to teach and assist children aged 6 to7 years old to study at home during the COVID-19 pandemic $(71.10 \%)$. As many as $78.20 \%$ of mothers want their children to return to the school and taught by the teacher.
\end{abstract}

Keywords: Parental challenges; children aged 6 to7 years old; learning during COVID-19

Copyright (c) 2021 Novitawati, Chresty Anggreani

$\triangle$ Corresponding author :

Email Address: rika_hardi@yahoo.com (Riau, Indonesia)

Received 27 March 2021, Accepted 19 April 2021, Published 22 April 2021 


\section{PENDAHULUAN}

Semenjak merebaknya virus COVID- 19 di dunia serta dinyatakan pandemi pada bulan Maret di Indonesia, seluruh kegiatan kehidupan jadi berganti serta terbatas (WHO, 2020). Dikala itu dimulailah pembatasan interaksi raga ialah dengan metode guru serta siswa bekerja serta belajar dari rumah demi menghindari penyebaran COVID-19. Semenjak dinyatakan pandemi, nyaris segala sekolah melakukan sistem belajar dari rumah (Learning from Home) dengan meniadakan belajar tatap muka langsung serta ditukar dengan Pendidikan Jarak Jauh (PJJ) memakai internet (Abidah et al., 2020).

Pandemi berakibat pada aktivitas belajar di sekolah- sekolah di Indonesia (Ro'fah et al., 2020). Proses belajar anak jadi berganti, beban orang tua juga jadi meningkat. Beberapa bulan sejak pandemi COVID- 19 berlangsung, timbul wacana kalau anak- anak akan bersekolah kembali. Wacana normal baru pada ranah pembelajaran tersebut menimbulkan konsekuensi yang beragam. Sebagian orang tua menarik nafas lega sebab anaknya akan kembali bersekolah dan tugas mereka mendidik anak di rumah juga akan menurun. Tetapi, tidak sedikit orang tua yang takut dengan pelaksanaan kebijakan tersebut sebab akumulasi permasalahan COVID-19 baru setiap hari masih sangat tinggi (Siagian, 2020). Sehingga akan sangat berisiko membiarkan kanak- kanak masuk sekolah yang bisa membuat kluster baru untuk penyebaran virus corona. Tetapi Pada akhir bulan Mei 2020 pemerintah secara formal mengumumkan penundaan masuk sekolah untuk seluruh jenjang sekolah.

Dampak COVID-19 terhadap proses pendidikan pada anak sekolah sangat banyak (Putri et al., 2020). Salah satunya diberlakukannya PJJ yaitu proses belajar dengan memakai tata cara sinkronus seperti menggunakan Google Meet, Zoom ataupun Whatsapp Call dan dengan memakai tata cara asinkronus dengan menggunakan Google Class Room (GCR) ataupun chat di tim Whatsapp ataupun Line. Tetapi banyak sekolah yang tidak sanggup mempraktikkan pembelajaran jarak jauh ini akibat akses internet yang tidak mencukupi. Tidak hanya itu, tidak sedikit orang tua murid yang kesusahan menyediakan sarana internet di rumah untuk melaksanakan PJJ karena keterbatasan keadaan ekonomi (Irawan et al., 2020; Lase et al., 2020) Hambatan teknis yang lain ialah keterbatasan akses internet sebab posisi tempat tinggal( contoh: tinggal di desa) yang menimbulkan banyak siswa kesusahan melaksanakan PJJ. Dengan keadaan yang bermacam-macam ini hingga sekolah- sekolah kesimpulannya mempraktikkan metode- metode pendidikan yang variatif. Selaku contoh, terdapat sekolah yang lumayan tidak berubah- ubah memakai tata cara interaktif online( contoh: pemakaian video conference) serta terdapat pula yang tidak mempraktikkan tata cara tatap muka secara online serta lebih memilah membagikan tugas lewat media komunikasi online semacam Whatsapp. Sebagian sekolah yang tidak mempunyai opsi buat mempraktikkan tata cara online learning memohon orang tua ataupun siswa tiba ke sekolah buat menjemput tugas yang diberikan.

Secara universal, sisi positif pandemi yang bisa diobservasi antara lain: 1) homeschooling meningkatkan keakraban antara anak serta ibu dan bapaknya, meningkatkan kualitas ikatan anak-orang tua; 2) anak- anak mempunyai waktu luang lebih banyak serta waktu belajar bisa ditetatapkan sendiri sesuai keinginan orang tua serta anak; 3) orang tua bisa mengikutsertakan anak dalam melaksanakan pekerjaan rumah bersama yang bisa meningkatkan keahlian motorik serta tanggungjawab anak; 4) anak belajar menggunakan technical devices yang menunjang kompetensi Information and Communication Technology( ICT) anak; 5) akses modul pelajaran menjadi sangat fleksibel; 6) menurunkan probabilitas anak terinfeksi COVID- 19 sebab kegiatan setiap hari anak terbatas cuma di area rumah (Nurfauziah, M. A., Raharjo, S. T., \& Krisnani, 2020).

Selain berdampak positif, pandemi COVID- 19 ini juga berakibat negatif untuk anak serta orang tuanya (Putri et al., 2020). Tidak seluruh anak patuh mematuhi agar tinggal di rumah, belajar serta bermain di dalam rumah, dan mengerjakan tugas sekolah secara tertib. Sebagian besar anak merasa jenuh sebab lama tidak masuk sekolah sedangkan tugas sekolah sangat banyak (Wiresti, 2020; Irawan et al., 2020). Kejenuhan pada anak dapat dipicu oleh 
ketidaksiapan serta keahlian orang tua dalam mempersiapkan sarana belajar anak di rumah (Irawan et al., 2020; Lase et al., 2020). Tidak hanya itu, absennya offline learning membuat orang tua wajib jadi tutor belajar sekalian caregiver tiap waktu untuk anak- anaknya. Hal ini bisa berakibat negatif terhadap aspek psikologis orang tua sehingga membuat ikatan anak serta orang tua jadi tidak harmonis. Contohnya, orang tua terindikasi kerap memarahi anakanaknya sebab tingkah laku mereka yang tidak sempurna sehingga membuat anak terus menjadi tidak betah berada di dalam rumah (Wiresti, 2020).

Anak umur 6-7 tahun (usia dini) adalah seseorang yang sedang dalam proses pertumbuhan (Syaodih, 2015), baik secara fisik, kognitif, ataupun emosi (Suhada, 2016). Pada umur ini,(saat dimulainya pendidikan resmi di sekolah), fungsi kognitif anak tumbuh sangat pesat. Konsekuensinya bisa diobservasi lewat sikap anak yang tumbuh dari tataran simpel mengarah ke yang lebih kompleks. Didukung dengan pertumbuhan biologis (paling utama fungsi motorik, lihat (Suhada, 2016) anak mulai sanggup melaksanakan aktivitas teratur tiap hari secara mandiri. Anak umur 6-7 tahun sedang berada pada masa peralihan dari sesi praoperasional serta tahap operasional konkret (Syaodih, 2015), amati pula 4 tahap pertumbuhan dari Piaget dalam (de Ribaupierre, 2015). Pada tahap praoperasional, anak mulai sanggup paham simbol sehingga mengakomodir pelajaran menulis serta membaca. Pada peralihan ke tahap operasional konkret, anak mulai sanggup menampung informasi tentang konsep konservasi, klasifikasi serta seriasi. Oleh karenanya anak- anak umur 6-7 tahun telah memahami angka, telah sanggup menulis walaupun belum mudah serta telah dapat diajar membaca lancar.

Sebagai tambahan, pada umur 6-7 tahun, mereka sanggup mengelompokkan bendabenda pada aspek tertentu, misalnya warna, wujud ataupun besaran serta mulai paham konsep urutan (misalnya mengurutkan benda dari yang besar mengarah ke yang kecil). Keahlian ini merupakan dasar mereka agar bisa melakukan tugas- tugas di sekolah yang menuntut keahlian intelektual ataupun keahlian kognitif semacam membaca, menulis, serta berhitung (Stephens, 2007.; Limanto, 2014). Pada periode ini anak telah mempunyai keahlian berhitung, angka) misalnya menambah, mengurangi, mengalikan serta membagi.

Pertumbuhan psikologis serta sosial usia dini berbeda dengan anak umur bayi. Pertumbuhan psikologis anak umur dini (6-7 tahun) telah mempunyai motivasi yang relatif besar buat belajar serta mereka senang melihat orangtua atau gurunya bahagia (Syaodih, 2015). Tetapi umur 6-7 tahun merupakan umur bermain atau baru awal masuk sekolah, dan masih banyak di usia tersebut belum bisa membaca serta menulis. Secara universal, pada sesi ini orang tua (ibu) sangat berpengaruh besar dalam menolong guru dalam mengajarkan anak membaca, menulis serta berhitung (Christianti, 2015). Pelaksanaan konsep PJJ dimasa pandemi membuat orang tua wajib jadi satu-satunya guru pengajar baca-tulis offline anak disamping menolong anak mengerjakan tugas-tugas sekolah yang lain. Dengan keadaan rumah yang bermacam- macam (contohnya: kedua orang tua bekerja sehingga orang tua tidak memiliki banyak waktu buat mengajar anaknya ataupun orang tua yang tidak mempunyai latar belakang pendidikan yang tinggi sehingga mereka merasa sulit menjadi guru anaknya), pengalaman awal anak belajar membaca serta menulis jadi sangat variatif. Pandemi COVID19 mengganti paradigma literasi dini: guru tidak lagi jadi aspek utama kesuksesan belajar anak (Johansson et al., 2015), peran ini sudah dipikul seluruhnya oleh orang tua.

Anak usia dini diajar untuk memiliki kemampuan menulis, membaca , membaca serta berhitung (Christianti, 2015), karena kemampuan- kemampuan ini merupakan elemen dasar yang jadi prasyarat agar bisa menguasai pelajaran- pelajaran berikutnya (Stephens, 2007; Limanto, 2014). Kemampuan- kemampuan ini hendaknya mulai diasah semenjak umur pra sekolah sehingga saat mulai sekolah anak telah mempunyai bekal yang lumayan baik buat menerima informasi- informasi baru.

Suasana pandemi COVID-19 mewajibkan anak untuk tinggal serta belajar di rumah. Tugas guru yang sepatutnya mengarahkan menulis, membaca, serta berhitung telah digantikan oleh orang tua. Situasi yang tiba- tiba sangat menyulitkan seluruh pihak: orang tua 
wajib memikul tanggung jawab serta kedudukan baru selaku tutor belajar, sedangkan sekolah wajib mempersiapkan tata cara PJJ yang efisien serta efektif (Alifia et al., 2020). Dari perspektif orang tua, waktu mendampingi anak belajar sangat terbatas bila mereka wajib bekerja di luar rumah. Ini berakibat pada mutu dan hasil belajar anak yang sangat tidak sempurna (Alifia et al., 2020). Tidak hanya itu, sebagian tata cara belajar PJJ terindikasi tidak memikirkan keadaan orang tua yang bekerja sehingga siswa diberikan tugas- tugas yang relatif banyak dengan batasan waktu pengumpulan tugas yang pendek.

Dengan seluruh permasalahan serta fenomena yang dijabarkan di atas, sangat memungkinkan bila siswa akhirnya menghadapi kesulitan belajar dari rumah. Perpanjangan belajar di rumah berpotensi memunculkan rasa jenuh serta permasalahan emosi pada anak (Wiresti, 2020), yang utama pada anak di umur 6-7 tahun yang baru pertama sekali bersekolah, konsep homeschooling jadi lebih berat serta jadi tantangan besar untuk orang tua untuk membantu anak membuat tugas- tugas sekolah juga mengajarkan membaca serta menulis. Tujuan penelitian ini adalah untuk mengetahui tantangan orangtua terutama ibu-ibu dalam mendampingi anak usia 6-7 tahun belajar di rumah selama Pandemi COVID-19.

\section{METODOLOGI}

Penelitian ini dilaksanakan di kota Pekanbaru pada bulan November 2020. Penelitian ini adalah penelitian kuantitatif dengan metode cross sectional. Data didapatkan dengan menggunakan kuesioner yang didistribusikan melalui google form. Respondennya adalah ibu-ibu yang mempunyai anak umur 6- 7 tahun serta telah belajar memakai metode PJJ online ataupun dengan membagikan tugas yang langsung dijemput ke sekolah disesuaikan dengan agenda yang telah disepakati bersama guru. Jumlah responden yang terjaring dengan tata cara online tersebut sebanyak 526 responden (rata- rata umur ibu= 33 tahun; $S D=4.71$ ), yaitu ibuibu yang sedang mendampingi anak umur 6- 7(rata- rata umur anak $=6.42$ tahun; $S D=0.81 \%$, dimana $51.60 \%$ nya merupakan laki-laki serta $41.30 \%$ merupakan perempuan.

Data yang terkumpul dianalisis menggunakan SPSS serta dibahas dengan menyamakan konsep teoritis yang ada. Pada tata cara pengumpulan data yang terencana, peneliti melaksanakan tahapan penelitian dari tahap persiapan berupa literature review, rumusan masalah, pengumpulan data serta analisa data. Data penelitian ini menggunakan analisis deskriptif data kuantitatif. Data kuantitatif dianalisis secara univariat yang meliputi frekuensi dan persentase, serta korelasional dengan menggunakan Chi-Square. Gambaran desain penelitian dapat dilihat pada gambar 1 .

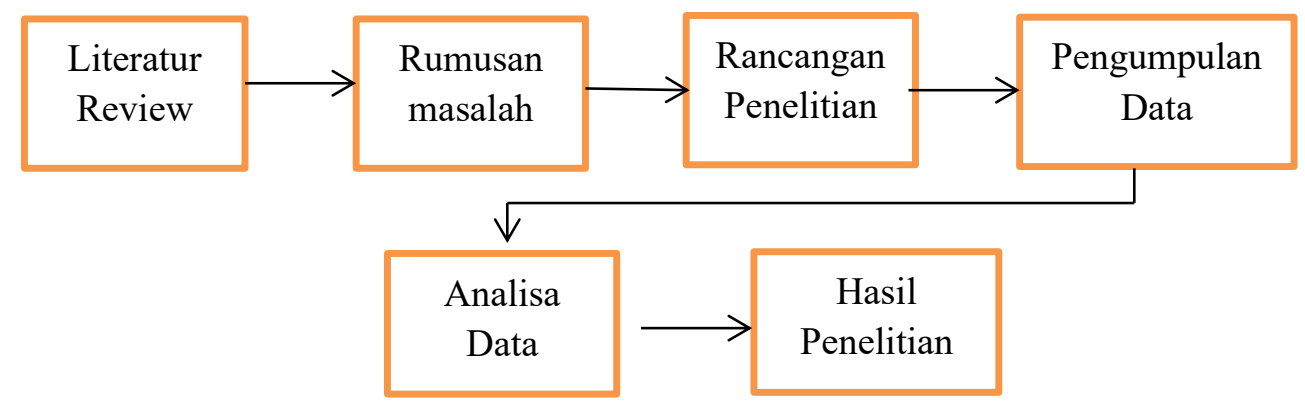

Gambar 1. Bagan desain penelitian

\section{HASIL DAN PEMBAHASAN}

Pandemi COVID- 19 merubah secara signifikan proses belajar mengajar di sekolah. Bisa dikatakan apapun bentuk metode PJJ, baik tata cara pendidikan interaktif secara online maupun tata cara PJJ dengan menjemput tugas- tugas ke sekolah (Abidah et al., 2020) akan berakibat bagi seluruh aktor yang ikut serta dalam proses belajar mengajar, mulai dari guru, orang tua serta anak didik sendiri. Lewat penelitian ini, kami berupaya memberi informasi 
hasil survei berbentuk data deskriptif terkait tantangan- tantangan yang dialami orang tua dalam mendampingi anak- anaknya yang baru masuk sekolah belajar di rumah.

Tabel 1. Metode Pembelajaran yang Digunakan di Sekolah

\begin{tabular}{lll}
\hline Metode PJJ & $\mathrm{N}$ & Persentase \\
\hline Menggunakan WA & 164 & 31.2 \\
Menggunakan GCR & 23 & 4.4 \\
Mengambil tugas ke sekolah & 339 & 64.4 \\
\hline & 526 & 100 \\
\hline
\end{tabular}

Tabel 1 menjelaskan bahwa penemuan awal berkaitan tentang tata cara PJJ yang diterapkan oleh sekolah. Dari 526 responden di dalam penelitian ini, 64. 40\% (339 ibu) melaporkan kalau orang tua wajib mengambil tugas- tugas yang diberikan guru di sekolah. Tugas umumnya diambil di hari- hari yang sudah ditetapkan (contoh: Senin dan Rabu) serta tugas ini dikumpulkan pada hari Sabtu di minggu tersebut. Bila tugas diberikan secara online (disebutkan oleh 35\% responden) memakai platform tertentu (contoh: Google Classroom) ataupun aplikasi komunikasi online (contoh: Whatsapp), tugas- tugas tersebut wajib dikumpulkan pada hari Rabu ataupun Sabtu. Instan, anak cuma mempunyai waktu 2 sampai 4 hari buat menuntaskan tugas- tugas yang diberikan serta orang tua wajib menolong anakanaknya agar bisa tercapai tugas belajar yang diberikan guru maupun kurikulum.

Tabel 2. Hasil belajar Pembelajaran Jarak Jauh

\begin{tabular}{lll}
\hline Hasil belajar & $\mathrm{N}$ & Persentase \\
\hline Paham & 74 & 24 \\
Kurang paham & 452 & 86 \\
Tidak paham & 0 & 0 \\
\hline & 526 & 100 \\
\hline
\end{tabular}

Tabel 2 menjelaskan dari sisi anggapan orang tua tentang hasil belajar, dan hasil kuesioner menginformasikan bahwa 452 orang tua ( $86.00 \%$ dari responden) melaporkan kalau anak mereka kurang menguasai tugas-tugas yang diberikan oleh guru sebab jumlah tugas yang relatif banyak serta waktu pengerjaan tugas yang lumayan pendek.

Tabel 3. Pengumpulan Tugas Tepat Waktu

\begin{tabular}{lll}
\hline Tugas Tepat Waktu & $\mathrm{N}$ & Persentase \\
\hline Ya & 265 & 50.4 \\
Tidak & 187 & 35.6 \\
Kadang-kadang & 74 & 14 \\
\hline & 526 & 100 \\
\hline
\end{tabular}

Tabel 3 menjelaskan bahwa pemberian tugas lewat media grup Whatsapp dipersepsikan orang tua sebagai suatu hambatan sebab media ini susah didokumentasikan sehingga menyulitkan orang tua memahami petunjuk serta tugas yang diberikan guru. Dari hasil survei ini, tidak mengherankan bila banyak siswa yang tidak bisa mengumpulkan seluruh tugas yang diberikan dalam waktu yang didetetapkan (35.6\%). Sebagian kecil dari orang tua (74 orang, 14. 00\%) merespon positif tentang uraian tugas yang diberikan oleh guru. Kelompok orang tua ini juga mempersepsi kalau anaknya sanggup mengerjakan tugas yang diberikan dengan baik, meski untuk itu orang tua (ibu) wajib menyedikan waktu yang lumayan banyak dalam mendampingi anaknya belajar. 
Tabel 4. Kesesuaian Tugas yang Diberikan oleh Guru

\begin{tabular}{lcl}
\hline Kesesuaian Tugas & $\mathrm{N}$ & Persentase \\
\hline Sesuai & 466 & 88.6 \\
Tidak & 60 & 11.4 \\
\hline & 526 & 100 \\
\hline
\end{tabular}

Tentang kesesuaian tugas yang diberikan oleh guru dengan keahlian anak umur 6-7 tahun, $88.60 \%$ orang tua memberikan reaksi positif, artinya menurut pandangan orang tua, tugas- tugas yang diberikan oleh guru tersebut sudah cocok dengan tahap pertumbuhan anak mereka. Tugas- tugas ini biasanya meliputi tugas menulis, membaca dan kadang- kadang tugas berhitung. Khusus untuk tugas membaca, peran aktif orang tua sangat dibutuhkan sebab mereka harus mengarahkan anak membaca mengikuti panduan tugas yang telah diberikan oleh guru.

Tabel 5. Jenis Tugas Pendampingan Orangtua

\begin{tabular}{lll}
\hline Tugas Pendampingan & $\mathrm{N}$ & Persentase \\
\hline Membimbing menulis & 244 & 46.40 \\
$\begin{array}{l}\text { Membacakan tugas guru } \\
\text { Membantu menuliskan tugas }\end{array}$ & 160 & 30.40 \\
guru & 122 & 23.20 \\
\hline & 526 & 100 \\
\hline
\end{tabular}

Sebaliknya untuk tugas menulis, $46.40 \%$ orang tua menginformasikan bahwa mereka wajib menerangkan serta membimbing anaknya belajar menulis di rumah, 30.40\% melaporkan kalau mereka cuma mendampingi serta membacakan tugas dari guru, sedangkan $23.20 \%$ yang lain menginformasikan kalau mereka cuma membantu menuliskan tugas dari guru. Melalui data ini, bisa dikatakan kalau sebagian besar orang tua wajib aktif berfungsi jadi tutor utama (jika tidak salah satunya) dalam proses literasi resmi awal untuk anak- anaknya.

Tabel 6. Kesulitan Mendampingi Anak Belajar di Rumah

\begin{tabular}{lll}
\hline Kesulitan Mendampingi & $\mathrm{N}$ & Persentase \\
\hline Sulit & 374 & 71.10 \\
Tidak sulit & 152 & 28.90 \\
\hline & 526 & 100 \\
\hline
\end{tabular}

Secara umum hasil penelitian ini menyatakan bahwa sebagian besar orangtua $(71.10 \%)$ menyatakan sulit mendampingi anak belajar di rumah untuk mengerjakan tugas-tugas dari guru, dan sebanyak 152 orang tua (28.90\%) menyatakan tidak menemui kesulitan yang berarti dalam masalah ini. Untuk mendeskripsikan hasil ini, analisis korelasional dengan memakai Chi Square yang menunjukkan bahwa kesusahan orang tua dalam mendampingi anakanaknya berkaitan dengan status pekerjaan mereka dimana sebanyak 282 orang ibu di dalam ilustrasi ini $(53.60 \%)$ merupakan ibu-ibu bekerja $(p<.05)$, serta ini mengkonfirmasi alasan tentang orang tua (utama ibu) bekerja yang sudah dijabarkan di atas.

Menulis dan membaca pada usia dini adalah kegiatan yang lumayan berat diajarkan kepada anak umur 6-7 tahun (Stephens, 2007). Di masa pandemi COVID- 19 ini peran orang tua dalam mendampingi anaknya belajar membaca serta menulis jadi lebih besar daripada di masa saat sebelum pandemi. Dengan keadaan ini, bisa dipahami bila sebagian besar dari orang tua (411 orang, 78. 20\% responden) menginginkan supaya anak mereka bisa belajar bersama guru di sekolah. Meski sebagian kecil orang tua (115 orang, 21. 80\% responden) senantiasa memandang PJJ selaku opsi yang pas karena menurunkan probabilitas anakanaknya tertular COVID- 19. 
Secara garis besar, kuantitas tugas, waktu pengerjaan yang pendek, tata cara penyampaian modul pelajaran yang tidak efisien serta tingginya tuntutan terhadap orang tua pasti mempunyai akibat yang signifikan terhadap tingkatan keadaan psikologis orang tua dan mutu hasil belajar anak. Penelitian yang dilaksanakan pada masa pandemi COVID- 19 menampilkan tingkatan well- being yang mengkhawatirkan pada keluarga yang mempunyai anak umur sekolah serta relatif rendahnya kepuasan orang tua terhadap manajemen waktu anak- anaknya dibanding saat sebelum pandemic (Andresen et al., 2020). Paling utama pada ibu yang bekerja, PJJ bisa meningkatkan konflik internal pada ibu dalam memilah karir ataupun keluarga (Callaghan, 2005) dan mengganggu fikiran yang dalam waktu panjang bisa memunculkan akibat negatif pada keadaan psikologis ibu.

Terkait korelasi antara PJJ serta kompetensi kognitif anak, penelitian sebelum pandemi menampilkan kalau pada masa libur masa panas (lebih kurang 2 bulan), anak- anak mengalami penurunan kompetensi akademis sampai 10\% standar deviasi (Alexander et al., 2007). Bila libur sekolah yang relatif pendek saja dapat membawa akibat yang cukup signifikan terhadap kompetensi kognitif, bisa diasumsikan pelaksanaan PJJ yang berkelanjutan dapat membawa akibat negatif yang sistematis terhadap kompetensi akademis anak.

Dari hasil analisis data, dapat dilihat jika sebagian besar orang tua mempunyai permasalahan dengan merode PJJ yang sudah diterapkan. Menurut (Bhamani et al., 2020) serta (Ahmad, 2020) salah satu tata cara yang cukup efektif dalam mempraktikkan konsep PJJ tanpa memberikan beban banyak pada orang tua yaitu dengan memanfaatkan teknologi yang maksimal, misalnya memakai audio visual, belajar interaktif online, menggunakan permainan yang menarik sehingga meningkatkan ketertarikan serta motivasi pada anak. Dengan metode ini peran guru dalam proses PJJ bisa lebih dimaksimalkan serta peran orang tua bisa sedikit direduksi sebab anak tidak membutuhkan pendampingan yang selalu dari orang tua (Sari et al., 2020; Kordi \& Baharudin, 2010). Pada awal pelaksanaan PJJ yang tiba- tiba, memang persiapan sarana yang mendukung pendidikan online sangat sedikit sehingga orang tua wajib bersiap diri menjadi pendamping belajar anak- anaknya supaya mutu belajar anak di masa pandemi COVID- 19 senantiasa maksimal serta mencapai hasil sesuai yang ditargetkan oleh kurikulum ataupun guru sekolah (Bhamani et al., 2020). Namun dikala PJJ telah diterapkan berbulan- bulan, menjadi suatu keharusan jika pihak sekolah, guru, lembaga pemerintah serta segala aktor yang ikut serta dalam regulasi sistem pembelajaran mampu menyusun program serta tata cara PJJ yang optimal sehingga satu sisi mendukung perkembangan kompetensi anak serta sisi lain memberikan keringanan pada orang tua dalam mendampingi anaknya belajar di rumah.

\section{SIMPULAN}

Banyak ibu-ibu yang merasakan kesulitan membagi waktu antara mengarahkan anak belajar di rumah dengan pekerjaan yang wajib dikerjakannya, sebagai ibu rumah tangga ataupun sebagai pekerja ataupun berdagang. Sebagian besar ibu berkata bahwa anak-anaknya kurang mengerti dengan tugas yang diberikan oleh gurunya sehingga orang tualah yang mengerjakan tugas tersebut. Sehubungan dengan beratnya tantangan orang tua dalam mengarahkan anak belajar di rumah, orang tua menginginkan anaknya kembali bersekolah seperti biasa agar lebih paham dalam menangkap pelajaran dari guru.

\section{UCAPAN TERIMA KASIH}

Ucapan terimakasih kepada seluruh pihak yang sudah menolong sehingga terlaksananya penelitian ini, khusunya ibu- ibu yang telah bersedia jadi responden. Ucapan terimakasih juga peneliti sampaikan kepada Sekolah-sekolah yang telah membantu dalam proses penyebaran kuesioner kepada ibu- ibu yang mempunyai aanak-anak umur 6-7 tahun. 


\section{DAFTAR PUSTAKA}

Abidah, A., Hidaayatullaah, H. N., Simamora, R. M., Fehabutar, D., \& Mutakinati, L. (2020). The Impact of Covid-19 to Indonesian Education and Its Relation to the Philosophy of "Merdeka Belajar." Studies in Philosophy of Science and Education, 1(1), 38-49. https://doi.org/10.46627/sipose.v1i1.9

Ahmad, I. F. (2020). Asesmen Alternatif Dalam Pembelajaran Jarak Jauh Pada Masa Darurat Penyebaran Coronavirus Disease (Covid-19) Di Indonesia. PEDAGOGIK: Jurnal Pendidikan, 7(1), 195-222. https:// doi.org/10.33650/pjp.v7i1.1136

Alexander, K. L., Entwisle, D. R., \& Olson, L. S. (2007). Lasting consequences of the summer learning gap. American Sociological Review, 72(2), 167-180. https://doi.org/10.1177/000312240707200202

Alifia, U., Barasa, A. R., Bima, L., Pramana, R. P., Revina, S., \& Tresnatri, F. A. (2020). Learning from Home: Portrait of Teaching and Learning Inequalities in Times of The Covid-19 Pandemic. Smeru Research Note, 1(1), 1-8.

Andresen, S., Lips, A., Möller, R., Rusack, T., Schröer, W., Thomas, S., \& Wilmes, J. (2020). Kinder, Eltern und ihre Erfahrungen während der Corona-Pandemie: Erste Ergebnisse der bundesweiten Studie KiCo. Gematika Jurnal Manajemen Informatika, 1-23. https://www.forum-

transfer.de/fileadmin/uploads/Bibliothek/Wichtiges_Wissen_für_alle/KiCo_Famili enCorona.pdf

Bhamani, S., Makhdoom, A. Z., Bharuchi, V., Ali, N., Kaleem, S., \& Ahmed, D. (2020). Home Learning in Times of COVID: Experiences of Parents. Journal of Education and Educational Development, 7(1), 9. https:// doi.org/10.22555/joeed.v7i1.3260

Callaghan, J. (2005). Book Review: Competing Devotions: Career and Family Among Women

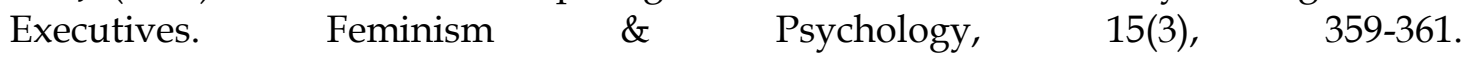
https://doi.org/10.1177/095935350501500310

Christianti, M. (2015). Membaca dan Menulis Permulaan Untuk Anak Usia Dini. Jurnal Pendidikan Anak, 2(2). https:// doi.org/10.21831/jpa.v2i2.3042

de Ribaupierre, A. (2015). Piaget's Theory of Cognitive Development. In International Encyclopedia of the Social \& Behavioral Sciences: Second Edition (pp. 120-124). https:// doi.org/10.1016/B978-0-08-097086-8.23093-6

Irawan, A. W., Dwisona, D., \& Lestari, M. (2020). Psychological Impacts of Students on Online Learning During the Pandemic COVID-19. KONSELI: Jurnal Bimbingan Dan Konseling (E-Journal), 7(1), 53-60https:// doi.org/10.24042/kons.v7i1.6389

Johansson, S., Myrberg, E., \& Rosén, M. (2015). Formal Teacher Competence and its Effect on Pupil Reading Achievement. Scandinavian Journal of Educational Research, 59(5), 564582. https:// doi.org/10.1080/00313831.2014.965787

Kordi, A., \& Baharudin, R. (2010). Parenting Attitude and Style and Its Effect on Children's School Achievements. International Journal of Psychological Studies, 2(2). https://doi.org/10.5539/ijps.v2n2p217

Lase, D., Zaluchu, S. E., Daeli, D. O., \& Ndraha, A. (2020). Parents' Perceptions of Distance Learning during Covid-19 Pandemic in Rural Indonesia (Issue December). https://doi.org/10.35542/osf.io/hfza7

Limanto, S. (2008). Peningkatan Minat dan Kemampuan Anak Usia Pra Sekolah untuk Belajar Membaca dan Menulis Permulaan Menggunakan Komputer Aided Learning. GEMATIKA Jurnal Manajemen Informatika, 9(2), 63-120.

Nurfauziah, M. A., Raharjo, S. T., \& Krisnani, H. (2020). Dampak Pembelajaran Daring Terhadap Anak Selama Pandemi Covid-19. Researchgate. https://www.researchgate.net/publication/342353957_DAMPAK_PEMBELAJARA N_DARING_TERHADAP_ANAK_SELAMA_PANDEMI_COVID-19

Putri, R. S., Purwanto, D., Purwanto, A., Pramono, R., Asbari, M., Wijayanti, L. M., \& Hyun, C. C. (2020). Impact of the COVID-19 pandemic on online home learning: An 
explorative study of primary schools in Indonesia. International Journal of Advanced Science and Technology, 29(5), 4809-4818.

Ro'fah, R., Hanjarwati, A., \& Suprihatiningrum, J. (2020). Is Online Learning Accessible During COVID-19 Pandemic? Voices and Experiences of UIN Sunan Kalijaga Students with Disabilities. Nadwa, 14(1), 1-38. https://doi.org/10.21580/nw.2020.14.1.5672

Sari, I., Sinaga, P., Hernani, H., \& Solfarina, S. (2020). Chemistry Learning via Distance Learning during the Covid-19 Pandemic. Tadris: Jurnal Keguruan Dan Ilmu Tarbiyah, 5(1), 155-165. https:// doi.org/10.24042/tadris.v5i1.6346

Siagian, T. H. (2020). Corona Dengan Discourse Network Analysis. Jurnal Kebijakan Kesehatan Indonesia, 09(02), 98-106.

Stephens, K. (n.d.). Creative Ways to Lead Kids to Reading and Writing.

Suhada, I. (2016). Psikologi Perkembangan Anak Usia Dini (Raudhatul Athfal). Bandung: Remaja Rosda Karya, 176.

Syaodih, E. (2015). Perkembangan anak usia dini (6-8 tahun). Pelatihan Pembelajaran Terpadu Yayasan Pendidikan Salman Al Farisi 2003, 1-22.

Who. (2020). COVID-19 oxygen emergency impacting more than half a million people in lowand middle-income countries every day, as demand surges. Who. https://www.who.int/news/item/25-02-2021-covid-19-oxygen-emergencyimpacting-more-than-half-a-million-people-in-low--and-middle-income-countriesevery-day-as-demand-surges

Wiresti, R. D. (2020). Analisis Dampak Work From Home pada Anak Usia Dini di Masa Pandemi Covid-19. Jurnal Obsesi: Jurnal Pendidikan Anak Usia Dini, 5(1), 641. https://doi.org/10.31004/obsesi.v5i1.563 